\title{
Combined Quantitative X-ray Diffraction, Scanning Electron Microscopy, and Transmission Electron Microscopy Investigations of Crystal Evolution in $\mathrm{CaO}-\mathrm{Al}_{2} \mathrm{O}_{3}-\mathrm{SiO}_{2}-\mathrm{TiO}_{2}-\mathrm{ZrO}_{2}-\mathrm{Nd}_{2} \mathrm{O}_{3}-\mathrm{Na}_{2} \mathrm{O}$ System
}

Chang-Zhong Liao, ${ }^{\dagger, \ddagger}$ Chengshuai Liu, ${ }^{\S}$ Po-Heng Lee, ${ }^{\prime}$ Martin C. Stennett, ${ }^{\perp}$ Neil C. Hyatt, ${ }^{*}, \perp$ and Kaimin Shih*,+(1)

${ }^{\dagger}$ Guangdong Key Laboratory of Agricultural Environment Pollution Integrated Control, Guangdong Institute of Eco-Environmental and Soil Sciences, Guangzhou 510650, P. R. China

${ }^{\ddagger}$ Department of Civil Engineering, The University of Hong Kong, Pokfulam, Hong Kong SAR

${ }^{\S}$ State Key Laboratory of Environmental Geochemistry, Institute of Geochemistry, Chinese Academy of Sciences, Guiyang 550009, P. R. China

"Department of Civil \& Environmental Engineering, The Hong Kong Polytechnic University, Hong Kong SAR, P. R. China

${ }^{\perp}$ Immobilisation Science Laboratory, Department of Materials Science and Engineering, The University of Sheffield, Sheffield S1 3JD, U.K.

Supporting Information

ABSTRACT: Glass-ceramics, with a specific crystalline phase assembly, can combine the advantages of glass and ceramic and avoid their disadvantages. In this study, both cubic-zirconia and zirconolite-based glass-ceramics were obtained by the crystallization of $\mathrm{SiO}_{2}-\mathrm{CaO}-$ $\mathrm{Al}_{2} \mathrm{O}_{3}-\mathrm{TiO}_{2}-\mathrm{ZrO}_{2}-\mathrm{Nd}_{2} \mathrm{O}_{3}-\mathrm{Na}_{2} \mathrm{O}$ glass. Results show that all samples underwent a phase transformation from cubic-zirconia to zirconolite when crystallized at 900,950 , and $1000{ }^{\circ} \mathrm{C}$. The size of the cubic-zirconia crystal could be controlled by temperature and dwelling time. Both cubiczirconia and zirconolite crystals/particles show dendrite shapes, but with different dendrite branching. The dendrite cubic-zirconia showed highly
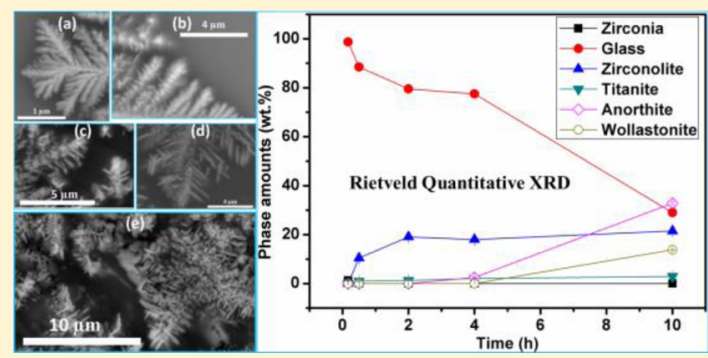
oriented growth. Scanning electron microscopy images show that the branches of the cubic-zirconia crystal had a snowflake-like appearance, while those in zirconolite were composed of many individual crystals. Rietveld quantitative analysis revealed that the maximum amount of zirconolite was $\sim 19 \mathrm{wt} \%$. A two-stage crystallization method was used to obtain different microstructures of zirconolite-based glass-ceramic. The amount of zirconolite remained approximately $19 \mathrm{wt} \%$, but the individual crystals were smaller and more homogeneously dispersed in the dendrite structure than those obtained from one-stage crystallization. This process-control feature can result in different sizes and morphologies of cubic-zirconia and zirconolite crystals to facilitate the design of glass-ceramic waste forms for nuclear wastes.

\section{INTRODUCTION}

Nuclear power is a low-carbon energy source that significantly reduces greenhouse gas emissions. However, public acceptance of nuclear power has faced immense challenges throughout the world, especially since the Fukushima Daiichi accident in March 2011. ${ }^{1}$ A key public concern is the management of radioactive waste generated by nuclear reactors. Following several decades of study, the short-lived and low-level radioactive wastes are routinely disposed of in certified sites; however, the disposal of high-level radioactive waste (HLW) still faces a number of challenges. In HLW, the radiotoxicity remaining after 200-300 years' disposal is expected to mostly arise from the long-lived radionuclides of $\mathrm{Np}, \mathrm{Am}$, and $\mathrm{Cm}^{2}$ To minimize disposal costs and environmental damage, it has been suggested that these long-lived radionuclides be separated and immobilized in a specific waste-form matrix. Many potential such waste forms have been proposed for disposing of HLW, which can be classified into glass, ceramic, and glass-ceramic. ${ }^{3}$ The glassy waste forms, such as borosilicate glass and phosphate glass, have been used on an industrial scale in many countries. ${ }^{4}$ These waste forms can incorporate a wide range of radionuclides and perform well in terms of chemical durability, hence their widespread use. However, the minor actinides $(\mathrm{Np}, \mathrm{Am}, \mathrm{Cm})$ have very low solubilities in the glassy waste forms. ${ }^{4}$ The ceramic waste form has excellent radiation stability, chemical durability, and chemical flexibility. However, it is challenging to produce a single-crystalline phase for the immobilization of minor actinides. ${ }^{3}$ In addition, alpha decay

Received: October 4, 2016

Revised: January 9, 2017

Published: January 11, 2017 
from the radionuclides in the ceramic waste form can result in a crystalline-to-amorphous phase transition, which leads to reduced chemical durability and inferior physical properties. The glass-ceramic waste form offers the possibility of avoiding the drawbacks of both glassy and ceramic waste forms while exploiting their advantages for the disposal of HLW. ${ }^{3}$ The concept of double-barrier containment using glass-ceramics has the potential to greatly reduce the leaching rate of radionuclides into the biosphere.

In the glass-ceramic waste form, the choice of crystalline phase for incorporating radionuclides into the crystallographic sites is crucial. Generally, the potential candidates are the crystalline phases of the ceramic waste forms. These crystalline phases have been proposed to immobilize minor actinides $(\mathrm{Np}$, $\mathrm{Am}, \mathrm{Cm}$ ) and have been found to stably coexist with actinides within the Earth over geologic time scales. Both cubic-zirconia and zirconolite are fluorite-derived structures with high radiation tolerance to amorphization and high chemical durability. ${ }^{5}$ It has been reported that $\mathrm{ThO}_{2}, \mathrm{UO}_{2}$, and $\mathrm{PuO}_{2}$ have high solubilities in cubic-zirconia. ${ }^{6-8}$ This implies that the incorporation of actinides $(\mathrm{Pu}, \mathrm{Np}, \mathrm{Am}, \mathrm{Cm})$ into cubiczirconia should be possible, because their ionic radii are similar to those of Th and U. Meldrum ${ }^{9}$ observed that bulk zirconia was not amorphized even at radiation doses reaching $680 \mathrm{dpa}$ (displacements per atom). Actinides have been found as impurities in the structure of natural zirconolite. ${ }^{10}$ Zirconolite also shows excellent resistance to aqueous dissolution in a wide range of $\mathrm{pH}$ values; even the radiation-amorphized material shows a very low leaching rate. ${ }^{11}$ Thus, cubic-zirconia and/or zirconolite are potential crystalline phases in glass-ceramic waste forms for the immobilization of actinides ( $\mathrm{Np}, \mathrm{Am}, \mathrm{Cm}$ ).

As a double barrier for radionuclides, ${ }^{12}$ the ideal scenario for the glass-ceramic matrix is that all of the radionuclides are captured by the designed crystalline phase and that the residual glass encapsulates the crystalline phase effectively. However, in practice, the radionuclides show some degree of solubility in the residual glass. ${ }^{13}$ To increase the distribution of radionuclides into the crystalline phase, one potential method is to increase the amount of the crystalline phase in the glass-ceramic matrix. A greater crystalline fraction can also enhance the chemical and radiation durability of the glass-ceramic matrix. Quantitative X-ray diffraction analysis with a spiked standard reference is a powerful tool to quantify both the crystalline and amorphous phases in the materials. ${ }^{14-16}$ With this method, it is straightforward to optimize the experimental conditions to obtain a greater amount of the designed crystalline phase (such as cubic zirconia and zirconolite) in the glass-ceramic. In addition to the sheer quantity of the crystalline phase, the microstructure of this phase also strongly determines the radiation tolerance of the matrix. ${ }^{17}$ For a given crystalline fraction, smaller crystallites result in larger interfacial areas, which can hinder the accumulation of point defects and enhance the radiation tolerance. ${ }^{18-20}$ However, enlarging the interfacial areas will decrease the free-energy gap in the phase transformation between crystalline and amorphous phases, ${ }^{17}$ thus weakening the radiation tolerance. In the glass-ceramic system, the size of the interfacial areas is mainly determined by the size and morphology of the crystals, which are affected by the treatment temperature and time. ${ }^{21-24}$ Hence, it is essential to study the size and morphology of the crystals in the glassceramic.

In previous studies, a zirconolite-based glass-ceramic has been obtained in the $\mathrm{CaO}-\mathrm{Al}_{2} \mathrm{O}_{3}-\mathrm{SiO}_{2}-\mathrm{TiO}_{2}-\mathrm{ZrO}_{2}-\mathrm{Na}_{2} \mathrm{O}-$
$\mathrm{Nd}_{2} \mathrm{O}_{3}$ system. ${ }^{12,25-29}$ The phase transformation from cubiczirconia to zirconolite was observed in the temperature range of $950-1000{ }^{\circ} \mathrm{C}$. At temperatures from 1000 to $1200{ }^{\circ} \mathrm{C}$, only zirconolite was found in the bulk sample, while increased surface crystallization of titanite and anothite toward the bulk sample was also observed. However, the authors only studied the samples at temperatures ranging from 900 to $1350{ }^{\circ} \mathrm{C}$, with a fixed crystallization time $(2 \mathrm{~h})$. Therefore, the evolution of the crystal size and morphology of the sample as a function of the crystallization conditions (temperature and time) has not been studied in full. In particular, the amounts of cubic-zirconia and zirconolite obtained at different crystallization temperatures and times have not been investigated. To obtain a better glassceramic matrix, investigation of these parameters is necessary.

As indicated above, the amounts of the crystalline phases and the size and morphology of the crystallites play important roles in the performance of nuclear waste forms. In this study, the crystallization of $\mathrm{CaO}-\mathrm{Al}_{2} \mathrm{O}_{3}-\mathrm{SiO}_{2}-\mathrm{TiO}_{2}-\mathrm{ZrO}_{2}-\mathrm{Na}_{2} \mathrm{O}-$ $\mathrm{Nd}_{2} \mathrm{O}_{3}$ glass at 900,950 , and $1000{ }^{\circ} \mathrm{C}$ with different treatment times was systematically studied. Both cubic-zirconia-based glass-ceramic and zirconolite-based glass-ceramic were obtained from this glassy matrix. The evolution of the crystal size and morphology of the glassy matrix was characterized with a combination of transmission electron microscopy (TEM), scanning electron microscopy (SEM), electron backscatter diffraction (EBSD), powder X-ray diffraction (PXRD), and energy-dispersive X-ray spectroscopy (EDX). Rietveld quantitative phase analysis with a spiked standard reference $\left(\mathrm{Al}_{2} \mathrm{O}_{3}\right.$, SRM.676a) was used to quantify the phase contents (i.e., crystalline and amorphous).

\section{EXPERIMENTAL SECTION}

Glass-ceramic sample preparation: First, the parent glass was prepared with a chemical composition ${ }^{12}$ (by wt \%) of $\mathrm{SiO}_{2}$ (40.57), $\mathrm{Al}_{2} \mathrm{O}_{3}$ (11.95), $\mathrm{CaO}$ (19.63), $\mathrm{TiO}_{2}$ (12.45), $\mathrm{ZrO}_{2}$ (8.46), $\mathrm{Nd}_{2} \mathrm{O}_{3}$ (6.00), and $\mathrm{Na}_{2} \mathrm{O}$ (0.94). The parent glass was obtained as follows. Reagent-grade oxides $\left(\mathrm{SiO}_{2}, \mathrm{Al}_{2} \mathrm{O}_{3}, \mathrm{TiO}_{2}, \mathrm{ZrO}_{2}, \mathrm{Nd}_{2} \mathrm{O}_{3}\right)$ and carbonates $\left(\mathrm{CaCO}_{3}\right.$, $\mathrm{Na}_{2} \mathrm{CO}_{3} \cdot 10 \mathrm{H}_{2} \mathrm{O}$ ) were mixed, melted in a platinum crucible at 1500 ${ }^{\circ} \mathrm{C}$ for $9 \mathrm{~h}$, and then poured into an alumina crucible to be cooled in air. The obtained glass was further ground into powder, remelted at $1500{ }^{\circ} \mathrm{C}$ for $5 \mathrm{~h}$, and poured into the alumina crucible to cool in air again. The cast parent glass was annealed at $775{ }^{\circ} \mathrm{C}$ for $2 \mathrm{~h}$ to relieve the internal stresses and then cooled to room temperature. The glassceramic sample was obtained via a two-step fabrication route as described in the literature: ${ }^{28}$ (1) placing the parent glass into an 810 ${ }^{\circ} \mathrm{C}$ preheated furnace for $2 \mathrm{~h}$ of nucleation, and (2) transferring the sample to another furnace, which was preheated to the designated temperature $\left(900,950\right.$, or $\left.1000{ }^{\circ} \mathrm{C}\right)$, then dwelling the sample in the furnace for a designated period. After crystallization, the product was annealed at $775{ }^{\circ} \mathrm{C}$ for $2 \mathrm{~h}$ to relieve the internal stresses. For the samples with two crystallization stages, the parent glass was placed into an $810^{\circ} \mathrm{C}$ preheated furnace for $2 \mathrm{~h}$ nucleation, and then the product was transferred to another $900{ }^{\circ} \mathrm{C}$ preheated furnace for $10 \mathrm{~h}$ to crystallize, after which the temperature was increased to the designated value $\left(950\right.$ or $1000{ }^{\circ} \mathrm{C}$ ) in $10 \mathrm{~min}$ and held for $2 \mathrm{~h}$. Finally, the obtained glass-ceramic was also annealed at $775{ }^{\circ} \mathrm{C}$ for $2 \mathrm{~h}$ to relieve the internal stresses. These samples are denoted G-900-10h-950-2h or G-900-10h-1000-2h.

The X-ray powder diffraction data were collected using a D8 Advance diffractometer (Bruker AXS) with a Lynxeye detector, operating at $40 \mathrm{kV}$ and $40 \mathrm{~mA}$ with $\mathrm{Cu} \mathrm{K} \alpha$ radiation at room temperature. The $2 \theta$ scan range was from $10^{\circ}$ to $110^{\circ}$ (or $120^{\circ}$ ) with a step size of $0.02^{\circ}$ and a counting time of $1.5 \mathrm{~s}$. The quantitative X-ray diffraction (QXRD) analysis was carried out using TOPAS 4.2 software (Bruker AXS GmbH, Germany) with a fundamentalparameters approach. Because the investigated samples contained 
both crystalline and amorphous (glass) phases, all of the samples were mixed with 20 wt $\%$ of $\mathrm{Al}_{2} \mathrm{O}_{3}$ (NIST, SRM.676a) as the standard reference in our QXRD technique to assist the quantification of the amorphous content.

For SEM characterization, the samples were polished using decreasing grain sizes of diamond paste. The EBSD and TEM samples were prepared by mechanical thinning followed by ion-beam milling (Fischione model 1010 Ion Beam Milling). A Hitachi S4800 FEGSEM, Hitachi S-3400N with variable pressure and Leo 1530 FESEM were used to observe the sample morphology. The TEM-EDX analysis was performed on an FEI Tecnai G2 20 S-TWIN operated at $200 \mathrm{kV}$. The EBSD scan was performed on the Leo 1530 FESEM using commercial software from HKL Technology APS Ltd. (Oxford, UK). During EBSD characterization, the sample was tilted at $70^{\circ}$, and a scanning step size of $0.1 \mu \mathrm{m}$ was used for the electron beam.

\section{RESULTS AND DISCUSSION}

Quantitative Phase Transformation and Crystal Evolution at $900{ }^{\circ} \mathrm{C}$. Previously, Loiseau et al. studied a sample prepared under a single set of conditions $\left(900{ }^{\circ} \mathrm{C}\right.$ for 2 h) and observed the formation of a fluorite-type phase. ${ }^{28,29}$ In the present study, the sample was crystallized at $900{ }^{\circ} \mathrm{C}$ with different dwelling times $(0.5,2,4,10$, and $15 \mathrm{~h})$ after nucleating at $810{ }^{\circ} \mathrm{C}$ for $2 \mathrm{~h}$. In Figure 1a, the XRD results show that a
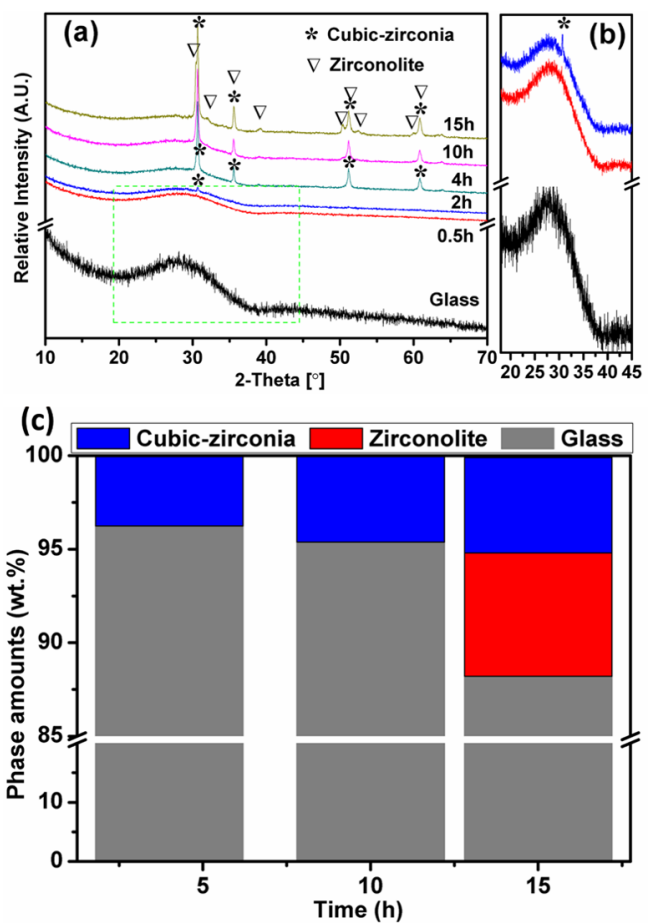

Figure 1. (a) XRD phase-identification results of parent glass and samples prepared by nucleation at $810^{\circ} \mathrm{C}$ for $2 \mathrm{~h}$ followed by crystal growth at $900{ }^{\circ} \mathrm{C}$ for different dwelling times $(t=0.5,2,4,10,15 \mathrm{~h})$; (b) details of the XRD patterns for parent glass and samples crystallized at $900{ }^{\circ} \mathrm{C}$ for 0.5 and $2 \mathrm{~h}$ after nucleation at $810^{\circ} \mathrm{C}$ for $2 \mathrm{~h}$; (c) XRD phase-quantification results of samples crystallized at $900{ }^{\circ} \mathrm{C}$ for 4,10 , and $15 \mathrm{~h}$ based on Rietveld refinement with addition of standard reference $\mathrm{Al}_{2} \mathrm{O}_{3}$.

single cubic-zirconia phase was present in the samples crystallized for 2,4 , and $10 \mathrm{~h}$, while both cubic-zirconia and zirconolite phases were observed for $15 \mathrm{~h}$ crystallization. The sample crystallized at $900{ }^{\circ} \mathrm{C}$ for $0.5 \mathrm{~h}$ became opaque (see Supporting Information, Figure S1), and a few small crystals (approximately $973 \mathrm{~nm}$ in size) were found in the SEM image
(Supporting Information, Figure S2). However, no obvious Bragg reflections were detected in the XRD pattern (Figure $1 b)$, indicating that the fraction of crystalline phase was below the detection limit of powder XRD. Using the spiked standard reference (NIST, SRM 676a), the amounts of both the glass and crystalline phases in the samples with 4,10 , and $15 \mathrm{~h}$ crystallization times were obtained (Figure 1c). In the sample crystallized for $4 \mathrm{~h}$, the percentage by weight of residual glass was $\sim 96.3$ wt $\%$, while that of cubic-zirconia was $\sim 3.7 \mathrm{wt} \%$. A greater percentage of cubic-zirconia $(\sim 4.6 \mathrm{wt} \%)$ was obtained when the crystallization time increased to $10 \mathrm{~h}$. Although the amounts of crystalline phases increased with increasing dwelling time, the content of residual glass was still very high ( $\sim 88 \mathrm{wt}$ $\%)$ after $15 \mathrm{~h}$ crystallization. The SEM images likewise show that the fractions of crystalline phases (cubic-zirconia and zirconolite) in the glass-ceramic samples (Figure 2) increased

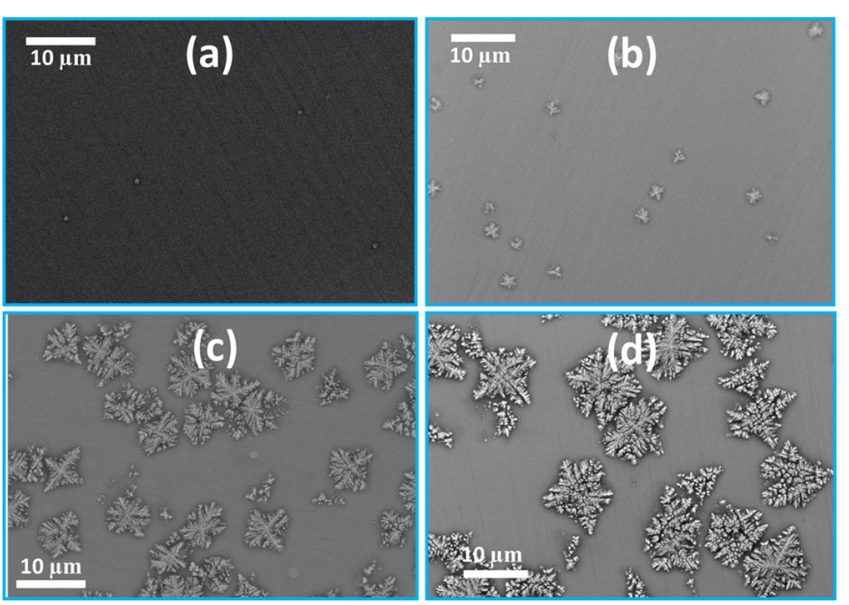

Figure 2. Backscattered SEM images of samples prepared by nucleation at $810^{\circ} \mathrm{C}$ for $2 \mathrm{~h}$ followed by crystal growth at $900{ }^{\circ} \mathrm{C}$ for different dwelling times $t$, (a) $t=0.5 \mathrm{~h}$; (b) $t=2 \mathrm{~h}$; (c) $t=4 \mathrm{~h}$; (d) $t=10 \mathrm{~h}$.

with increasing crystallization time. From Figure 2, we can see that the numbers of crystals/particles remained constant from 4 to $15 \mathrm{~h}$, even though the amounts of the crystalline phases increased. However, the size of the dendrite crystals/particles increased considerably from $\sim 1$ to $13 \mu$ m when prolonging the crystallization period (Figure 3 ). These results endorse the theory of nucleation and crystallization, ${ }^{21}$ in that sufficient nuclei were formed from the glass in the first stage, followed by crystal growth.

Furthermore, the growth of the cubic-zirconia crystals in this glass-ceramic system proved to be highly oriented. As shown in Figure 4, an inverse pole figure (IPF) map was scanned for a dendrite crystal in the $10 \mathrm{~h}$ crystallization sample, in which only the cubic-zirconia phase was identified by XRD. Only one color appeared in the Euler angle map, and the same was observed in each IPF map along the $x, y$, and $z$ axes. Because different orientations would be represented by different colors, the appearance of the same color in the Euler angle map and each individual IPF map indicates that the cubic-zirconia crystal grew in a single direction, and the entire dendrite can be considered as one crystal. Because radiation tolerance is related to the size and morphology of the crystal, this highly oriented growth of cubic-zirconia may enhance its radiation resistance and is thus deserving of further study. 


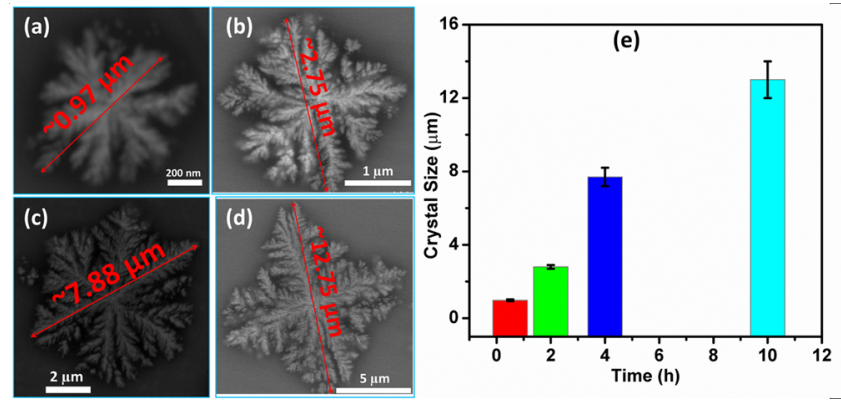

Figure 3. Backscattered SEM images of representative crystal in samples prepared by nucleation at $810^{\circ} \mathrm{C}$ for $2 \mathrm{~h}$ followed by crystal growth at $900{ }^{\circ} \mathrm{C}$ for different dwelling times $t$, (a) $t=0.5 \mathrm{~h}$; (b) $t=2$ $\mathrm{h}$; (c) $t=4 \mathrm{~h}$; (d) $t=10 \mathrm{~h}$; (e) crystal size of samples prepared by nucleation at $810{ }^{\circ} \mathrm{C}$ for $2 \mathrm{~h}$ followed by crystal growth at $900{ }^{\circ} \mathrm{C}$ for different dwelling times $(t=0.5,2,4$, and $10 \mathrm{~h})$.

Quantitative Phase Transformation and Crystal Evolution at $950{ }^{\circ} \mathrm{C}$. As shown in Figure 5a, cubic-zirconia was the only crystalline phase observed in the samples with shorter crystallization times $(0.5$ and $1 \mathrm{~h})$, while both crystalline phases (cubic-zirconia and zirconolite) appeared in the sample crystallized at $950{ }^{\circ} \mathrm{C}$ for $2 \mathrm{~h}$. In the samples crystallized for 4 and $6 \mathrm{~h}$, however, zirconolite was the only crystalline phase formed. These results indicate that the phase transformation of cubic-zirconia to zirconolite can occur even at $950{ }^{\circ} \mathrm{C}$ in the glass-ceramic system. This phase transformation is consistent with the results reported by Loiseau et al., who studied the same glass system, ${ }^{29}$ and by Vance, who used an alkoxide precursor to study the $\mathrm{CaZrTi}_{2} \mathrm{O}_{7}$ phase. ${ }^{30}$ In the above section, the sample crystallized at $900{ }^{\circ} \mathrm{C}$ also underwent such a phase transformation after dwelling for $15 \mathrm{~h}$. The occurrence of this phase transformation may be related to the crystal structures of cubic-zirconia and zirconolite, both of which are fluorite-related structures. ${ }^{11,31}$ After $10 \mathrm{~h}$ crystallization, anorthite and wollastonite were formed by the crystallization of residual glass in the bulk, which was rich in $\mathrm{CaO}, \mathrm{Al}_{2} \mathrm{O}_{3}$, and
$\mathrm{SiO}_{2}$. The titanite phase could not be quantified by PXRD due to its very low concentration, attributed to the thinness of the surface crystallization (less than $50 \mu \mathrm{m}){ }^{29}$ The quantitative phase analysis (Figure $5 \mathrm{~b}$ ) shows that residual glass remained the largest component in the glass-ceramic, although it decreased from $\sim 98.6$ wt $\%$ to 63.3 wt \% with increasing dwelling time from 0.5 to $10 \mathrm{~h}$. The maximum percentage of the zirconolite phase was $\sim 19$ wt $\%$, beyond which it remained nearly constant with prolonged crystallization time. The fractions of crystals in the bulk sample display the same trends in the SEM images (Figure 6). In Figure 6, the fraction of crystals increased with increasing dwelling time from 0.5 to $2 \mathrm{~h}$, but then remained nearly constant as the crystallization time was extended from 4 to $10 \mathrm{~h}$. These results indicate that the highest content of zirconolite that can be obtained in this glassceramic system at $950{ }^{\circ} \mathrm{C}$ is approximately $19 \mathrm{wt} \%$, a figure that cannot be improved by further increasing the crystallization time. In addition, it can be seen that there were cracks in the bulk sample after $10 \mathrm{~h}$ crystallization (Figure 6f). This phenomenon renders the sample unacceptable for a nuclear waste immobilization form, because the cracks will increase the surface area and consequently lead to an enhanced leaching rate of radionuclides.

The SEM images in Figure $7 \mathrm{a}-\mathrm{f}$ show a representative dendrite crystal of each crystallized sample. The size of the dendrite crystals/particles became progressively larger with increasing crystallization time, except for the sample crystallized at $950{ }^{\circ} \mathrm{C}$ for $10 \mathrm{~h}$ (Figure $7 \mathrm{~g}$ ). The size decreased in the $10 \mathrm{~h}$ crystallization sample, possibly due to the formation of anorthite and wollastonite, which led to the dispersion and separation of dendrite particles. In addition, the dendritic morphologies of cubic-zirconia and zirconolite were very different in their branches. The branches in the cubic-zirconia had a morphology that was snowflake-like in appearance (Figure $7 \mathrm{a}, \mathrm{b}$ ), whereas those in the zirconolite were composed of many small slices (Figure $7 \mathrm{~d}, \mathrm{e}$ ). These microstructural evolutions may be worthy of detailed investigation in the
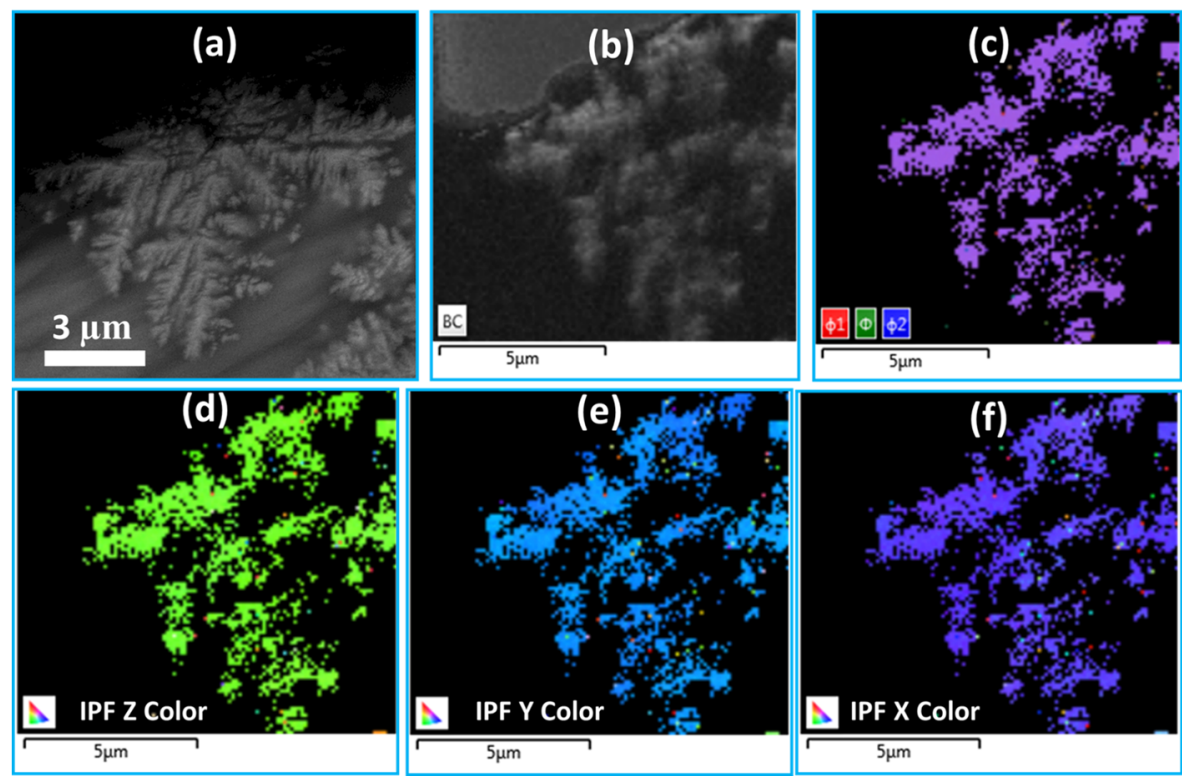

Figure 4. Electron backscatter diffraction results for sample prepared by nucleation at $810^{\circ} \mathrm{C}$ for $2 \mathrm{~h}$ followed by crystal growth at $900{ }^{\circ} \mathrm{C}$ for $10 \mathrm{~h}$, (a) Backscattered SEM image for the measured crystal; (b) band contrast for the measured area; (c) Euler angle map; (d) inverse pole figure (IPF) along the $z$-axis; (e) IPF along the $y$-axis; (f) IPF along the $x$-axis. In the IPF map, each color represents one orientation. 

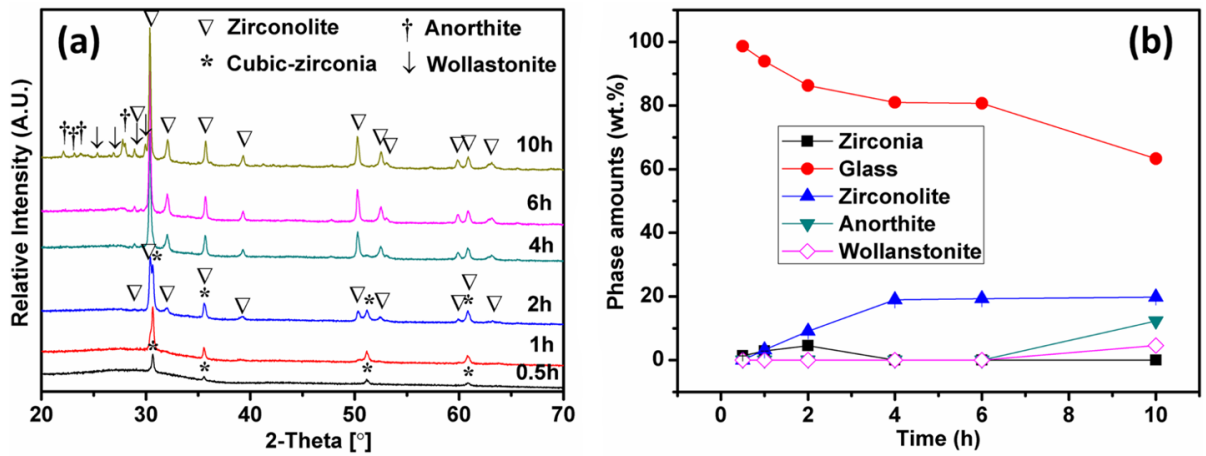

Figure 5. XRD phase-identification results (a) and quantification results (b) of samples prepared by nucleation at $810^{\circ} \mathrm{C}$ for $2 \mathrm{~h}$ followed by crystal growth at $950{ }^{\circ} \mathrm{C}$ for different dwelling times $(t=0.5,1,2,4,6$, and $10 \mathrm{~h})$.
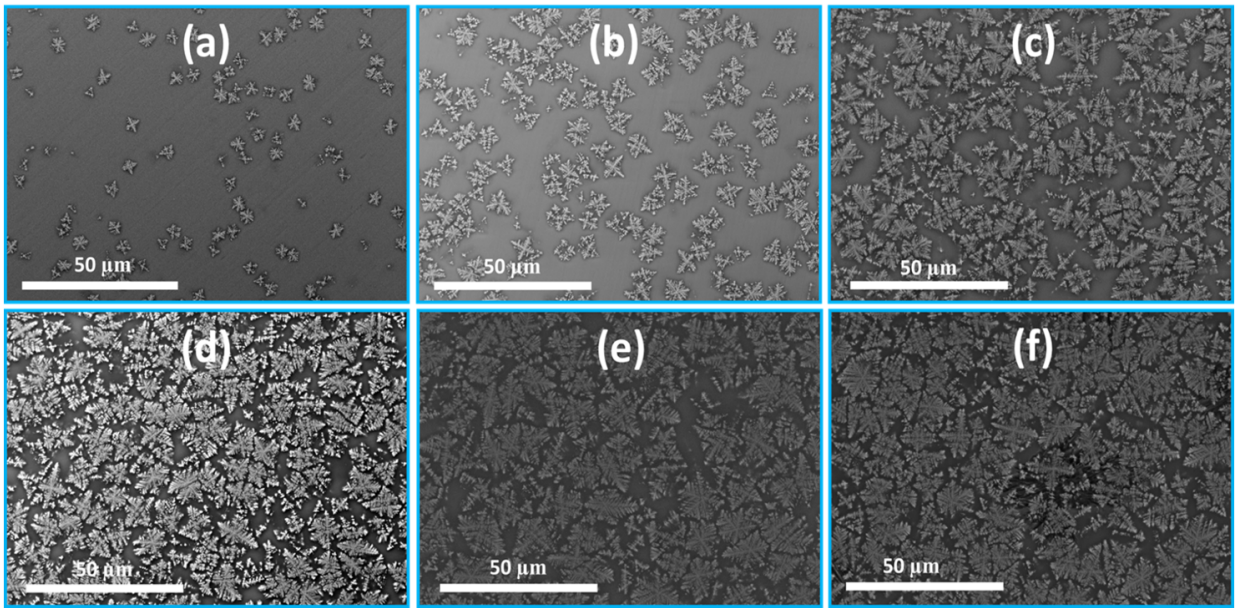

Figure 6. Backscattered SEM images of samples prepared by nucleation at $810{ }^{\circ} \mathrm{C}$ for $2 \mathrm{~h}$ followed by crystal growth at $950{ }^{\circ} \mathrm{C}$ for different dwelling times $t$, (a) $t=0.5 \mathrm{~h}$; (b) $t=1 \mathrm{~h}$; (c) $t=2 \mathrm{~h}$; (d) $t=4 \mathrm{~h}$; (e) $t=6 \mathrm{~h}$; (f) $t=10 \mathrm{~h}$.

context of radiation tolerance, because size and morphology effects play an important role in controlling the radiation damage. ${ }^{9,17-20}$

Evolution of Dendrite Crystals and Phase Transformation of Cubic-Zirconia to Zirconolite at $1000{ }^{\circ} \mathrm{C}$. As indicated in Figure 8a, the cubic-zirconia crystal was also the first phase to develop in the glass matrix at the beginning of the crystallization stage (after $10 \mathrm{~min}$ crystallization). The titanite phase was detected by PXRD after $0.5 \mathrm{~h}$ crystallization at 1000 ${ }^{\circ} \mathrm{C}$, although it was not observed even after $10 \mathrm{~h}$ crystallization at $950{ }^{\circ} \mathrm{C}$ (Figure 5a). Titanite was detectable at $1000{ }^{\circ} \mathrm{C}$ because the surface crystallization in the samples crystallized at that temperature had a greater thickness than in the samples crystallized at $950{ }^{\circ} \mathrm{C}$, sufficient to create an XRD-detectable quantity. These results also imply that the surface crystallization of the $\mathrm{CaO}-\mathrm{Al}_{2} \mathrm{O}_{3}-\mathrm{SiO}_{2}-\mathrm{TiO}_{2}-\mathrm{ZrO}_{2}-\mathrm{Nd}_{2} \mathrm{O}_{3}-\mathrm{Na}_{2} \mathrm{O}$ glass matrix is more sensitive to temperature than to dwelling time. Figure $8 \mathrm{a}$ also shows that only the zirconolite phase was observed in the bulk sample after 2 and $4 \mathrm{~h}$ crystallization. This suggests a potential fabrication route to obtain a single-phase zirconolite glass-ceramic product for actinide immobilization. With prolonged crystallization, additional crystalline phases (anorthite and wollastonite) were formed in the bulk sample. These two phases are not recommended waste forms for hosting actinides. ${ }^{32-34}$ Therefore, the products of 6 and $10 \mathrm{~h}$ crystallization were not suitable to use for actinide immobilization, although their zirconolite contents were higher than those in the 2 and $4 \mathrm{~h}$ crystallization samples. Figure $8 \mathrm{~b}$ shows that the residual glass was still the major component of the glassceramic product even after $4 \mathrm{~h}$ crystallization. The amounts of zirconolite in the samples crystallized for 2 and $4 \mathrm{~h}$ were similar $(\sim 19$ wt \%). This value is close to that in the samples crystallized for 4 and $6 \mathrm{~h}$ at $950{ }^{\circ} \mathrm{C}$. The similar crystallization results for zirconolite at 950 and $1000{ }^{\circ} \mathrm{C}$ indicate that it may be impossible to further increase the zirconolite content in this designed glass system only by adjusting the heat-treatment temperature and time. To obtain greater zirconolite contents, modifying the ratio of the chemical components of the glass system may prove an effective method, since increasing the contents of $\mathrm{ZrO}_{2}$ and $\mathrm{TiO}_{2}$ in the system was reported to enhance the zirconolite yield. ${ }^{35}$ In addition, the theoretical amount of zirconolite is about 23.3 wt \% which can be calculated based on the chemical compositions of parent glass if $\mathrm{ZrO}_{2}$ is completely transformed into the zirconolite phase. A lower formation of zirconolite $(\sim 19 \mathrm{wt} \%)$ than the theoretical value indicates the existences of $\mathrm{Zr}$ and $\mathrm{Ti}$ in the glass network.

Because zirconolite-based glass-ceramic is a potential doublebarrier waste form for actinide immobilization, studying the elemental distribution of the $\mathrm{Nd}$ (acting as a surrogate actinide) and other elements in the glass-ceramic system is critical for evaluating the immobilization ability. Figure 9 shows the TEMEDX line-scan profiles of the elements $\mathrm{Al}, \mathrm{Ca}, \mathrm{Nd}, \mathrm{Si}, \mathrm{Ti}$, and $\mathrm{Zr}$ across the zirconolite crystal in the sample crystallized at $1000{ }^{\circ} \mathrm{C}$ for $2 \mathrm{~h}$. From these profiles it is clear that $\mathrm{Nd}, \mathrm{Ti}$, and $\mathrm{Zr}$ were concentrated in the zirconolite crystal, while the residual glass was rich in $\mathrm{Si}$ and $\mathrm{Al}$. This result indicates that the 

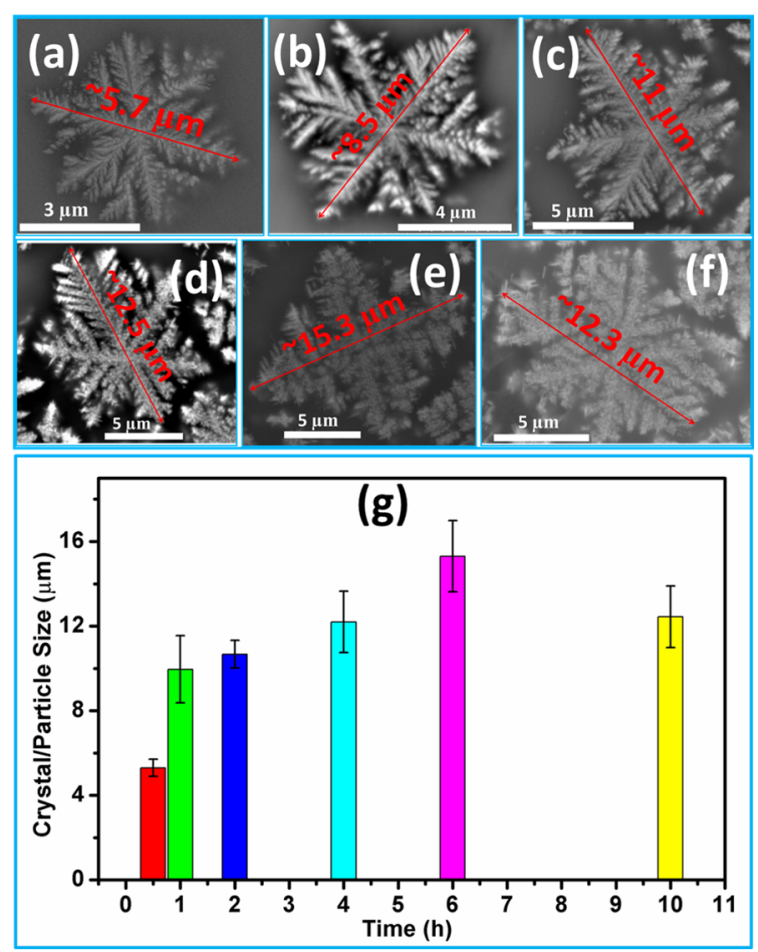

Figure 7. Backscattered SEM images of representative crystals in samples prepared by nucleation at $810{ }^{\circ} \mathrm{C}$ for $2 \mathrm{~h}$ followed by crystal growth at $950{ }^{\circ} \mathrm{C}$ for different dwelling times $t$, (a) $t=0.5 \mathrm{~h}$; (b) $t=1$ $\mathrm{h}$; (c) $t=2 \mathrm{~h}$; (d) $t=4 \mathrm{~h}$; (e) $t=6 \mathrm{~h}$; (f) $t=10 \mathrm{~h}$; (g) crystal size of samples prepared by nucleation at $810{ }^{\circ} \mathrm{C}$ for $2 \mathrm{~h}$ followed by crystal growth at $950{ }^{\circ} \mathrm{C}$ for different dwelling times $(t=0.5,1,2,4,6$, and 10 h).

zirconolite-based glass-ceramic is an excellent double barrier for $\mathrm{Nd}$ immobilization. Because both the zirconolite crystal and the Si-containing glass show good performance in terms of chemical durability, ${ }^{12,29,34}$ the residual glass (rich in $\mathrm{Si}$ and $\mathrm{Al}$ ) acts as the first barrier to hinder the leaching of radionuclides, and zirconolite as the second.

Figure 10 shows the details of crystal evolution from cubiczirconia to zirconolite and the crystal growth of zirconolite. In the early stage of crystallization, snowflake-shaped cubiczirconia crystals precipitated (Figure 10a); then, phase transformation from cubic-zirconia to zirconolite occurred, and many small, separated crystals of zirconolite became observable (Figure 10b). The length of an individual zirconolite crystal reached 1 to $2 \mu \mathrm{m}$ after $4 \mathrm{~h}$ crystallization (Figure 10d). With prolonged crystallization, many fractures and voids appeared in the bulk sample crystallized for $10 \mathrm{~h}$ (Figure 10e). The crystal evolution described above indicates that the crystal size and microstructure can be controlled by adjusting the processing time. This allows the crystal size and microstructure to be carefully controlled to enhance the radiation resistance.

Two-Stage Crystallization to Form Various Microstructures. Because the zirconolite phase was formed through the phase transformation of cubic-zirconia, and single zirconolite was obtained in the samples crystallized at both 950 and $1000{ }^{\circ} \mathrm{C}$, a fabrication protocol based on a two-stage crystallization was designed to obtain various morphologies of zirconolite crystals. After nucleation at $810{ }^{\circ} \mathrm{C}$ for $2 \mathrm{~h}$, the product was first crystallized at $900{ }^{\circ} \mathrm{C}$ for $10 \mathrm{~h}$ to obtain cubiczirconia, followed by crystallization at 950 or $1000{ }^{\circ} \mathrm{C}$ for $2 \mathrm{~h}$. Compared with the sample crystallized at $950{ }^{\circ} \mathrm{C}$ for $2 \mathrm{~h}$, the sample G-900-10h-950-2h (crystallized at $900{ }^{\circ} \mathrm{C}$ for $10 \mathrm{~h}$, then at $950{ }^{\circ} \mathrm{C}$ for $2 \mathrm{~h}$ ) yielded a greater fraction of zirconolite (Table 1) but still with a component of cubic-zirconia (Figure 11). The XRD patterns in both the G-900-10h-1000-2h sample (crystallized at $900{ }^{\circ} \mathrm{C}$ for $10 \mathrm{~h}$, then at $1000{ }^{\circ} \mathrm{C}$ for 2 $\mathrm{h}$ ) and the sample crystallized only at $1000{ }^{\circ} \mathrm{C}$ for $2 \mathrm{~h}$ were similar, and only the zirconolite phase was found in the bulk samples (Figure 12). Quantitative powder XRD analysis revealed that the quantity of zirconolite phase in both samples was $\sim 19$ wt $\%$ (Table 1 ). This result indicates that the two samples should possess similar abilities to incorporate actinide radionuclides into the zirconolite phase. Combined with the results at $950{ }^{\circ} \mathrm{C}$, it is reasonable to state that with its chemical composition fixed, the amount of zirconolite that can be obtained in this system is limited to approximately 19 wt \%. Furthermore, it is not feasible to increase the quantity of zirconolite by adjusting the temperature or treatment time in this system design.

Figure 13a,b shows the differences between the microstructures of the sample crystallized at $950{ }^{\circ} \mathrm{C}$ for $2 \mathrm{~h}$ and G900-10h-950-2h. The dendrite shapes of these two samples were similar, but the individual crystals in the G-900-10h950-2h sample were smaller than those in the sample crystallized at $950{ }^{\circ} \mathrm{C}$ for $2 \mathrm{~h}$. In Figure 14a,b, the branches in the dendrite shape of the sample crystallized only once, at $1000{ }^{\circ} \mathrm{C}$ for $2 \mathrm{~h}$, were clearly separated, while those in the G-

\section{(a)}

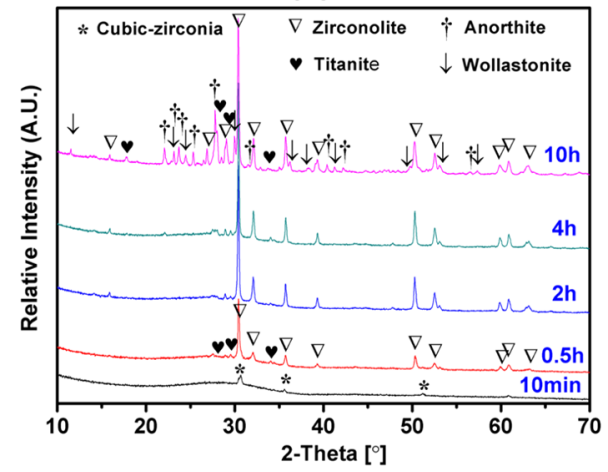

(b)

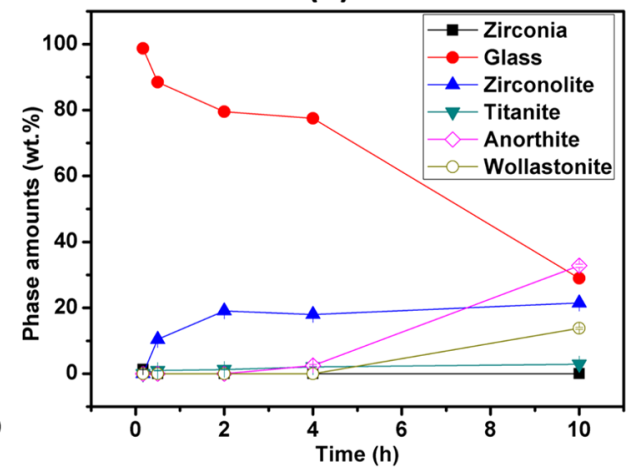

Figure 8. XRD phase-identification results (a) and quantification results (b) of samples prepared by nucleation at $810{ }^{\circ} \mathrm{C}$ for $2 \mathrm{~h}$ followed by crystal growth at $1000{ }^{\circ} \mathrm{C}$ for different dwelling times $(t=10 \mathrm{~min}, 0.5,2,4$, and $10 \mathrm{~h})$. 

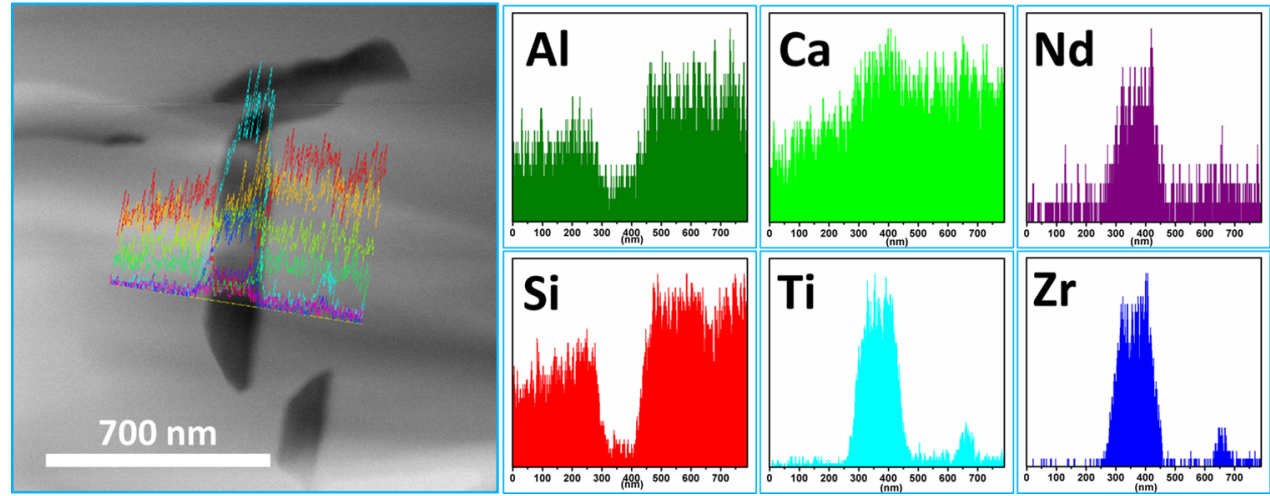

Figure 9. TEM-EDX line-scan profiles of the elements $\mathrm{Al}, \mathrm{Ca}, \mathrm{Nd}, \mathrm{Si}, \mathrm{Ti}$, and $\mathrm{Zr}$ across the zirconolite crystal.

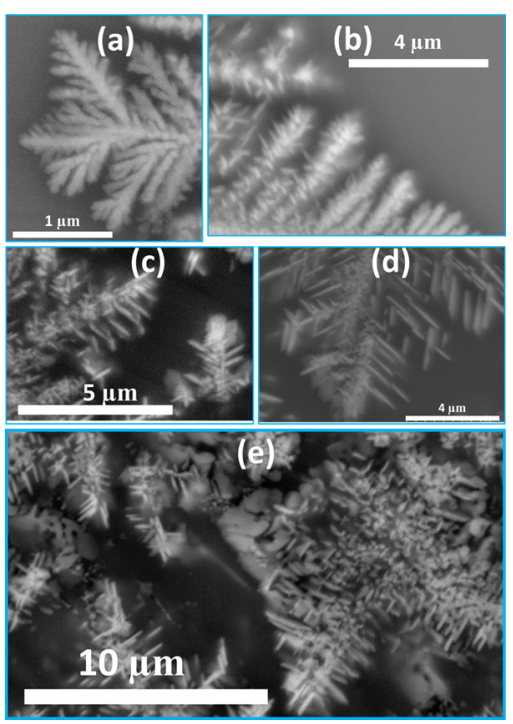

Figure 10. Backscattered SEM images of samples prepared by nucleation at $810^{\circ} \mathrm{C}$ for $2 \mathrm{~h}$ followed by crystal growth at $1000{ }^{\circ} \mathrm{C}$ for different dwelling times $t$, (a) $t=10 \mathrm{~min}$; (b) $t=0.5 \mathrm{~h}$; (c) $t=2 \mathrm{~h}$; (d) $t=4 \mathrm{~h}$; (e) $t=10 \mathrm{~h}$, showing the details of crystal evolution from cubic-zirconia to zirconolite and the crystal growth of zirconolite.

Table 1. XRD Phase-Quantification Results of Samples with One Crystallization Stage (Nucleation at $810{ }^{\circ} \mathrm{C}$ for $2 \mathrm{~h}$, Crystal Growth at 950 or $1000{ }^{\circ} \mathrm{C}$ for $2 \mathrm{~h}$ ) and Two Crystallization Stages ${ }^{a}$

\begin{tabular}{|lccc|}
\hline \multicolumn{1}{|c}{ sample ID } & cubic-zirconia & zirconolite & glass \\
\hline $950-2 \mathrm{~h}$ & $4.6(1)$ & $9.1(1)$ & $83.3(1)$ \\
$900-10 \mathrm{~h}$ plus $950-2 \mathrm{~h}$ & $2.4(1)$ & $16.0(1)$ & $81.6(2)$ \\
& titanite & zirconolite & glass \\
\hline 1000-2h & $1.3(1)$ & $19.1(1)$ & $79.5(2)$ \\
$900-10 \mathrm{~h}$ plus $1000-2 \mathrm{~h}$ & $1.0(1)$ & $18.9(1)$ & $80.1(2)$ \\
\hline
\end{tabular}

${ }^{a}$ Nucleation at $810{ }^{\circ} \mathrm{C}$ for $2 \mathrm{~h}$ and crystal growth at $900{ }^{\circ} \mathrm{C}$ for $10 \mathrm{~h}$ and then at 950 or $1000{ }^{\circ} \mathrm{C}$ for $2 \mathrm{~h}$.

900-10h-1000-2h sample overlapped heavily. The individual crystals in the G-900-10h-1000-2h sample were also smaller than those in the sample crystallized only once at $1000{ }^{\circ} \mathrm{C}$ for 2 h. These different microstructures may come from the different paths of obtaining zirconolite crystals through the two different processes. In the two-stage crystallization process, the first stage (crystallized at $900{ }^{\circ} \mathrm{C}$ for $10 \mathrm{~h}$ ) provided a sufficient time to obtain a large amount of cubic-zirconia crystals. In the second

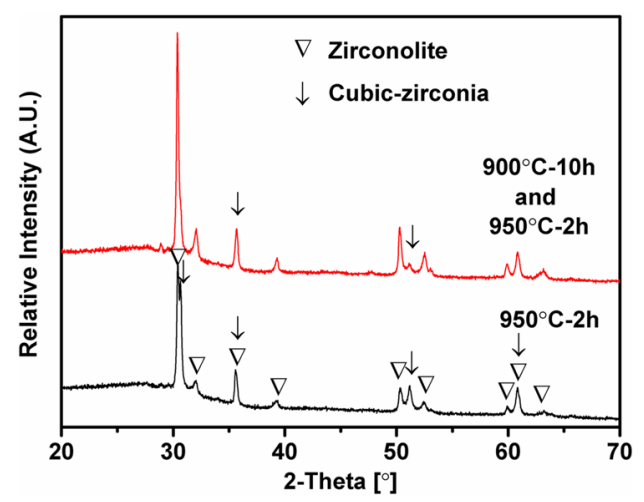

Figure 11. Comparison between XRD results of samples with one crystallization stage (nucleation at $810{ }^{\circ} \mathrm{C}$ for $2 \mathrm{~h}$, crystal growth at $950{ }^{\circ} \mathrm{C}$ for $2 \mathrm{~h}$ ) and two crystallization stages (nucleation at $810{ }^{\circ} \mathrm{C}$ for $2 \mathrm{~h}$ and crystal growth at $900{ }^{\circ} \mathrm{C}$ for $10 \mathrm{~h}$ and then at $950{ }^{\circ} \mathrm{C}$ for 2 h).

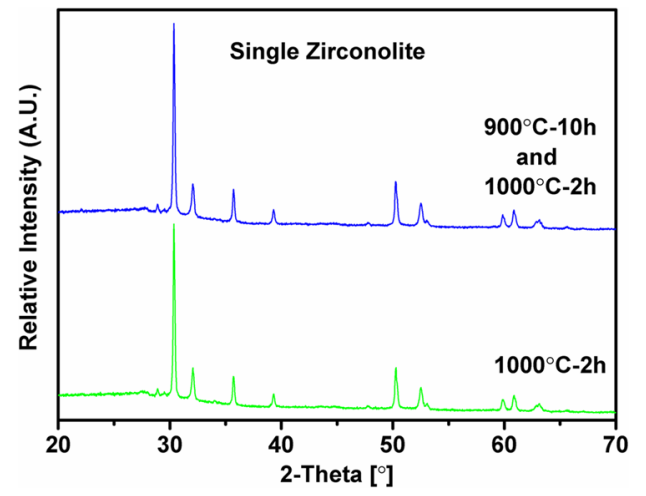

Figure 12. Comparison between XRD results of samples with one crystallization stage (nucleation at $810{ }^{\circ} \mathrm{C}$ for $2 \mathrm{~h}$, crystal growth at $1000{ }^{\circ} \mathrm{C}$ for $2 \mathrm{~h}$ ) and two crystallization stages (nucleation at $810^{\circ} \mathrm{C}$ for $2 \mathrm{~h}$ and crystal growth at $900{ }^{\circ} \mathrm{C}$ for $10 \mathrm{~h}$ and then at $1000{ }^{\circ} \mathrm{C}$ for 2 h).

stage, these cubic-zirconia crystals were transformed to zirconolites and continued to grow. Although cubic-zirconia also appeared first in the one-stage crystallization process, there was not enough time for growing into large crystals. These small cubic-zirconia crystals were subsequently transformed to zirconolite for the growth. In addition, the difference in the microstructures implies differences in the radiation tolerance of these two products, because the microstructure plays an important role in radiation stability. ${ }^{17-20}$ 


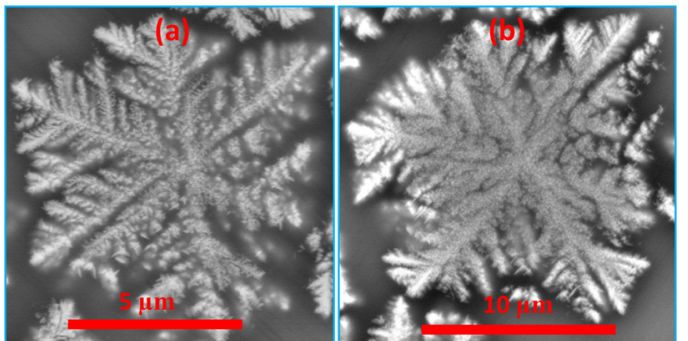

Figure 13. Backscattered SEM images of samples with (a) one crystallization stage (nucleation at $810{ }^{\circ} \mathrm{C}$ for $2 \mathrm{~h}$, crystal growth at $950{ }^{\circ} \mathrm{C}$ for $2 \mathrm{~h}$ ) and (b) two crystallization stages (nucleation at 810 ${ }^{\circ} \mathrm{C}$ for $2 \mathrm{~h}$ and crystal growth at $900{ }^{\circ} \mathrm{C}$ for $10 \mathrm{~h}$ and then at $950{ }^{\circ} \mathrm{C}$ for $2 \mathrm{~h}$ ).

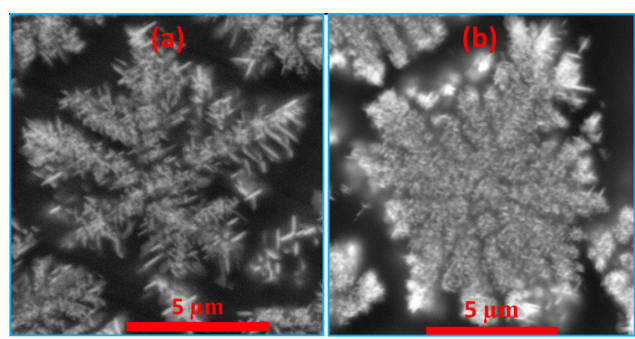

Figure 14. Backscattered SEM images of samples with (a) one crystallization stage (nucleation at $810^{\circ} \mathrm{C}$ for $2 \mathrm{~h}$, crystal growth at $1000{ }^{\circ} \mathrm{C}$ for $2 \mathrm{~h}$ ) and (b) two crystallization stages (nucleation at 810 ${ }^{\circ} \mathrm{C}$ for $2 \mathrm{~h}$ and crystal growth at $900{ }^{\circ} \mathrm{C}$ for $10 \mathrm{~h}$ and then at $1000{ }^{\circ} \mathrm{C}$ for $2 \mathrm{~h}$ ).

\section{CONCLUSION}

The crystallization of the $\mathrm{SiO}_{2}-\mathrm{CaO}-\mathrm{Al}_{2} \mathrm{O}_{3}-\mathrm{TiO}_{2}-\mathrm{ZrO}_{2}-$ $\mathrm{Nd}_{2} \mathrm{O}_{3}-\mathrm{Na}_{2} \mathrm{O}$ glass system at 900,950 , and $1000{ }^{\circ} \mathrm{C}$ with different dwelling times was systematically studied. Two specific crystalline phases (cubic-zirconia and zirconolite), which are potential waste forms for immobilizing actinide radionuclides, were grown from the glass matrix by a two-step method (nucleation + crystallization). After nucleation, all of the samples underwent a similar crystallization process at all temperatures $\left(900,950\right.$, and $1000^{\circ} \mathrm{C}$ ), in which cubic-zirconia was precipitated first and then transformed to the zirconolite phase. At $900{ }^{\circ} \mathrm{C}$, the size of the dendrite cubic-zirconia crystal could be controlled via the dwelling time, as could the quantity of the cubic-zirconia phase. In addition, this dendrite cubiczirconia crystal displayed highly oriented growth. Only zirconolite was obtained in the samples crystallized at $950{ }^{\circ} \mathrm{C}$ for both 4 and $6 \mathrm{~h}$. When crystallized at $950{ }^{\circ} \mathrm{C}$, the size of the dendrite particles (cubic-zirconia and/or zirconolite) increases with ongoing crystallization and reaches a maximum of $\sim 15$ $\mu \mathrm{m}$. The QXRD results show that regardless of how long the dwelling time was extended, the amount of zirconolite was limited to $\sim 19$ wt $\%$ when crystallized at 950 and $1000{ }^{\circ} \mathrm{C}$. At $1000{ }^{\circ} \mathrm{C}$, increasing the dwelling time led to the formation of anorthite and wollastonite, accompanied by the appearance of fractures and voids. It is interesting that both the cubic-zirconia and zirconolite crystals/particles showed dendrite shapes. However, the branches of the dendrites in cubic-zirconia had a snowflake-like appearance, while those in zirconolite were composed of many individual crystals. Even when produced by a two-stage crystallization procedure (crystallized at $900{ }^{\circ} \mathrm{C}$ for $10 \mathrm{~h}$, then at $1000{ }^{\circ} \mathrm{C}$ for $2 \mathrm{~h}$ ), the products contained a single zirconolite phase, and the amount of zirconolite was still limited to $\sim 19$ wt $\%$. However, their microstructures were markedly different from those produced by one-stage crystallization. This study provides a powerful method to fabricate and characterize cubic-zirconia/zirconolite-based glass-ceramics with different microstructures. The results will be useful for the design of suitable waste forms to dispose of high-level waste generated by commercial nuclear reactors or defense activities.

\section{ASSOCIATED CONTENT}

\section{S Supporting Information}

The Supporting Information is available free of charge on the ACS Publications website at DOI: 10.1021/acs.cgd.6b01458.

Figure S1 shows images of parent glass and samples prepared by nucleation at $810^{\circ} \mathrm{C}$ for $2 \mathrm{~h}$ followed by crystal growth at $900{ }^{\circ} \mathrm{C}$ for different dwelling times $t=$ $0.5,2$, and $4 \mathrm{~h}$. Figure S2 shows the backscattered SEM image of samples prepared by nucleation at $810{ }^{\circ} \mathrm{C}$ for 2 $\mathrm{h}$ followed by crystal growth at $900{ }^{\circ} \mathrm{C}$ for $0.5 \mathrm{~h}$ (PDF)

\section{AUTHOR INFORMATION}

\section{Corresponding Authors}

*(N.C.H.) E-mail: n.c.hyatt@sheffield.ac.uk; tel: +44 (0) 114 2225470; fax: +44 (0) 1142225943.

*(K.S.) E-mail: kshih@hku.hk; tel: +852 28591973; fax: +852 25595337.

ORCID ${ }^{\circ}$

Kaimin Shih: 0000-0002-6461-3207

Notes

The authors declare no competing financial interest.

\section{ACKNOWLEDGMENTS}

The authors thank Frankie Y. F. Chan for his help with the TEM experiments and the discussion. We gratefully acknowledge the funding for this research provided by the General Research Fund (17206714, 17212015) and Collaborative Research Fund (C7044-14G) of the Research Grants Council of Hong Kong, the One Hundred Talents Programme of the Chinese Academy of Sciences to C.L. and The Scientific Platform and Innovation Capability Construction Program of GDAS (2016GDASPT-0212). This research collaboration was also partly supported at the University of Sheffield by EPSRC under Grant References EP/N017870/1 and EP/L018616/1, and the MIDAS facility which was established with support from the Department of Energy and Climate Change. N.C.H. is also grateful to the Royal Academy of Engineering and the Nuclear Decommissioning Authority for founding support.

\section{REFERENCES}

(1) Chino, M.; Nakayama, H.; Nagai, H.; Terada, H.; Katata, G.; Yamazawa, H. J. Nucl. Sci. Technol. 2011, 48 (7), 1129-1134.

(2) Caurant, D.; Loiseau, P.; Majerus, O.; Aubin-Chevaldonnet, V.; Bardez, I.; Quintas, A. Glasses, Glass-Ceramics and Ceramics for Immobilization of Highly Radioactive Nuclear Wastes; Nova Science Publishers: New York, 2009.

(3) Lee, W. E.; Ojovan, M. I.; Stennett, M. C.; Hyatt, N. C. Adv. Appl. Ceram. 2006, 105 (1), 3-12.

(4) Weber, W. J.; Navrotsky, A.; Stefanovsky, S.; Vance, E. R.; Vernaz, E. MRS Bull. 2009, 34 (01), 46-53.

(5) Yudintsev, S. V.; Stefanovsky, S. V.; Ewing, R. C. In Structural Chemistry of Inorganic Actinide Compounds 2007, 457-490.

(6) Gong, W. L.; Lutze, W.; Ewing, R. C. J. J. Nucl. Mater. 2000, 277 (2-3), 239-249.

(7) Carroll, D. F. J. Am. Ceram. Soc. 1963, 46 (4), 194-195. 
(8) Cohen, I.; Schaner, B. E. J. Nucl. Mater. 1963, 9 (1), 18-52.

(9) Meldrum, A.; Boatner, L. A.; Ewing, R. C. Nucl. Instrum. Methods Phys. Res., Sect. B 2003, 207, 28-35.

(10) Whittle, K. R.; Hyatt, N. C.; Smith, K. L.; Margiolaki, I.; Berry, F. J.; Knight, K. S.; Lumpkin, G. R. Am. Mineral. 2012, 97 (2-3), 291-298.

(11) Lumpkin, G. R. Elements 2006, 2 (6), 365-372.

(12) Loiseau, P.; Caurant, D.; Majerus, O.; Baffier, N.; Mazerolles, L.; Fillet, C. Phys. Chem. Glasses 2002, 43C, 195-2000.

(13) Ojovan, M. I.; Lee, W. E. New Developments in Glassy Nuclear Wasteforms; Nova Publishers: New York, 2007.

(14) De La Torre, A. G.; Bruque, S.; Aranda, M. A. G. J. Appl. Crystallogr. 2001, 34 (2), 196-202.

(15) De la Torre, A. G.; Aranda, M. A. G. J. Appl. Crystallogr. 2003, 36 (5), 1169-1176.

(16) Gualtieri, A. F.; Riva, V.; Bresciani, A.; Maretti, S.; Tamburini, M.; Viani, A. J. Appl. Crystallogr. 2014, 47 (3), 835-846.

(17) Shen, T. D. Nucl. Instrum. Methods Phys. Res., Sect. B 2008, 266 (6), 921-925.

(18) Dey, S.; Drazin, J. W.; Wang, Y.; Valdez, J. A.; Holesinger, T. G.; Uberuaga, B. P.; Castro, R. H. R. Sci. Rep. 2015, 5, 7746.

(19) Shen, T. D.; Feng, S.; Tang, M.; Valdez, J. A.; Wang, Y.; Sickafus, K. E. Appl. Phys. Lett. 2007, 90 (26), 263115.

(20) Höchbauer, T.; Misra, A.; Hattar, K.; Hoagland, R. G. J. J. Appl. Phys. 2005, 98 (12), 123516.

(21) Holand, W.; Beall, G. H. Glass Ceramic Technology, 2nd ed.; John Wiley \& Sons: New York, 2012.

(22) Shanks, R. A.; Li, J.; Yu, L. Polymer 2000, 41 (6), 2133-2139.

(23) Jean, J.-H.; Fang, Y.-C.; Dai, S. X.; Wilcox, D. L. J. Am. Ceram. Soc. 2001, 84 (6), 1354-1360.

(24) Holand, W.; Rheinberger, V.; Schweiger, M. Philos. Trans. R. Soc., A 2003, 361 (1804), 575-589.

(25) Loiseau, P.; Caurant, D.; Baffier, N.; Fillet, C. Mater. Res. Soc. Symp. - Proc. 2003, 757, 243-250.

(26) Loiseau, P.; Caurant, D.; Baffier, N.; Fillet, C. Mater. Res. Soc. Symp. - Proc. 2001, 663, 169-177.

(27) Loiseau, P.; Caurant, D.; Baffier, N.; Mazerolles, L.; Fillet, C. Mater. Res. Soc. Symp. - Proc. 2001, 663, 179-187.

(28) Loiseau, P.; Caurant, D.; Baffier, N.; Mazerolles, L.; Fillet, C. J. J. Nucl. Mater. 2004, 335 (1), 14-32.

(29) Loiseau, P.; Caurant, D. J. Nucl. Mater. 2010, 402 (1), 38-54.

(30) Vance, E. R.; Ball, C. J.; Blackford, M. G.; Cassidy, D. J.; Smith,

K. L. J. Nucl. Mater. 1990, 175 (1-2), 58-66.

(31) Rossell, H. J. Nature 1980, 283 (5744), 282-283.

(32) Lumpkin, G. R.; Smith, K. L.; Giere, R.; Williams, C. T. Geol. Soc. Spec. Publ. 2004, 236 (1), 89-111.

(33) Ewing, R. C.; Weber, W. J.; Lian, J. J. Appl. Phys. 2004, 95, 5949-5971.

(34) Ewing, R. C.; Weber, W. J. The Chemistry of the Actinide and Transactinide Elements; Springer: Netherlands, 2011; pp 3813-3887.

(35) Loiseau, P.; Caurant, D.; Majerus, O.; Baffier, N.; Fillet, C. J. Mater. Sci. 2003, 38 (4), 853-864. 